\title{
Should Hepatitis C Virus Antibody Be Used for Screening Purposes?
}

\author{
Hepatit C Virüs Antikoru Tarama Amacıyla Kullanılmalı Mı?
}

\author{
๑ Birol ŞAFAK, ๑ Özge TOMBAK, • Aynur EREN TOPKAYA
}

Namık Kemal University Faculty of Medicine, Department of Medical Microbiology, Tekirdağ, Turkey

\begin{abstract}
Objectives: In this study, hepatitis C virus (HCV) RNA results were retrospectively investigated in patients with reactive $\mathrm{HCV}$ antibodies. Materials and Methods: HCV antibody test was performed ELISA method. Enzyme linked fluorescence assay was used as a different method. The quantitative HCV RNA test was carried out by AmpliPrep/COBAS TaqMan HCV test.

Results: HCV antibody reactivity was detected in 358 of 28081 samples, 255 samples collected from 358 anti-HCV positivepatients and were tested for HCV RNA were included in the study. The detected HCV RNA positivity rate was $5.8 \%$ in patients who had low titer reactive HCV antibody and $76.3 \%$ in patients, who had high titer reactive HCV antibody. Nine of 23980 samples, which were screened for preoperative preparation, had reactive HCV RNA. One hundred thirty seven of 4101 samples, which were obtained for diagnostic purposes in the gastroenterology and infectious diseases clinics, were HCV RNA positive.

Conclusion: Positive results should be confirmed with HCV RNA testing; if possible, testing for HCV antibodies with other methods, before HCV RNA testing, will decrease the number of tests using molecular methods; and screening for HCV antibodies is not costeffective especially in populations with a low prevalence of HCV antibody positivity.

Keywords: Hepatitis C virus antibody, screening, cost effectiveness
\end{abstract}

\section{OZZ}

Amaç: Bu çalışmada, reaktif hepatit $\mathrm{C}$ virüsü (HCV) antikorları olan hastalarda HCV RNA sonuçları retrospektif olarak incelendi. Gereç ve Yöntemler: HCV antikor testi ELISA yöntemi ile çalışıldı. Enzim Bağlantılı Floresans testi farkı bir yöntem olarak kullanılımıştır. Kantitatif HCV RNA testi AmpliPrep/COBAS TaqMan HCV testi ile gerçekleştirildi.

Bulgular: HCV antikoru için toplam 28081 numunenin 358'inde reaktivite tespit edildi. Çalışmaya anti-HCV antikoru pozitif 358 hastadan HCV RNA çalışılan 255 hasta örneği dahil edildi. Düşük titrede reaktif HCV antikoru olan hastalarda \%5,8 ve yüksek titrede reaktif HCV antikoru olan hastalarda \%76,3 HCV RNA pozitifliği saptandı. Preoperatif hazırlık kapsamında test edilen 23980 örneğin 9'unda HCV RNA pozitifti. Gastroenteroloji ve enfeksiyon hastalıkları kliniklerinden tanı amaçlı olarak gelen 4101 örneğinin 137'sinde HCV RNA pozitif idi.

Sonuç: Pozitif sonuçlar HCV RNA ile doğrulanmalıdır, eğer imkan varsa HCV RNA bakılmadan önce farklı bir yöntemle HCV antikoru çalışılmasının moleküler yöntemle çalışılacak test sayısını azaltacağı ve tarama amaçlı HCV antikoru bakılmasının özellikle düşük prevalanslı toplumlarda maliyet etkin olmadığı görüşüne varılmıştır. Anahtar Kelimeler: Hepatit C virüsü antikoru, tarama, maliyet etkinliği

Safak B, Tombak Ö, Eren Topkaya A. Should Hepatitis C Virus Antibody Be Used for Screening Purposes? Viral Hepat J. 2018;24:18-20.

\section{Introduction}

Hepatitis C virus $(\mathrm{HCV})$ can cause both acute and chronic hepatitis, ranging in severity from a mild condition lasting only a few weeks to a serious, lifelong illness. Acute HCV infection is usually asymptomatic and progresses only very rarely to a lifethreatening disease. The virus is spontaneously regresses without any treatment within 6 months in approximately $15 \%$ to $45 \%$ of infected persons. The remaining $60 \%$ to $80 \%$ of infected persons will develop chronic HCV infection. $15 \%$ to $30 \%$ of these patients with chronic $\mathrm{HCV}$ infection are at the risk of developing liver cirrhosis within 20 years (1). The rate of mortality due to HCVrelated diseases (mostly cirrhosis and hepatocellular carcinoma) shows a continuous increase (2). Central and South Asia, North 
Africa and Middle East have the highest HCV prevalence. The reported rate of the anti-HCV positivity is $1.6 \%$ worldwide and $0.4 \%-2.1 \%$ in our country (3). Laboratory tests play an important role in the diagnosis and follow-up of patients with chronic HCV infection. HCV antibody reactivity at the limit values is a serious problem for diagnostic laboratory practice. In the guidelines for $\mathrm{HCV}$ infection tests, HCV RNA analysis is recommended to confirm the $\mathrm{HCV}$ antibody reactivity and pseudo-reactivity $(2,4)$.

In this retrospective study, HCV RNA results of patients with low and high reactivity of $\mathrm{HCV}$ antibody referred for screening and diagnostic purposes were evaluated.

\section{Materials and Methods}

The results of the samples referred for HCV antibody screening between January 2016 and July 2017 were re-evaluated with a retrospective study design. HCV RNA results of patients with low titer $(\geq 1-<5$ sample cut-off $=\mathrm{S} / \mathrm{CO})$ and high titer $(\geq 5 \mathrm{~S} / \mathrm{CO}) \mathrm{HCV}$ antibodies for studied screening and diagnostic purposes were investigated in this study. HCV antibody test was first performed using enzyme-linked immunosorbent assay (ARCHITECT i2000 analyser; Abbott diagnostic, IL, USA). According to the manufacturer's recommendations, samples with a signal to cutoff ratio $(\mathrm{S} / \mathrm{CO})$ value of $\leq$ smaller than 1 were considered as non-reactive, while those with an $\mathrm{S} / \mathrm{CO}$ value of $\geq$ greater than or equal to 1 were considered reactive. Enzyme-linked fluorescence immunoassay (ELFA) (mini VIDAS; BioMérieux, Marcy l'Etoile, France) was used as a different method for samples with low reactivity. The quantitative HCV RNA assay was carried out with the COBAS AmpliPrep/COBAS TaqMan HCV Quantitative test v2.0 (Roche Molecular Systems, USA).

\section{Results}

Reactivity was detected in 358 of 28081 samples (1.27\%) which were analyzed for HCV antibody in our laboratory. Two hundred and fifty-five samples collected from 358 anti-HCV antibody positive patients and were tested for HCV RNA, were included in the study. The detected HCV RNA positivity rate was $5.8 \%(4 / 69)$ in patients who hadlow titer reactive HCV antibody and $76.3 \%(142 / 186)$ in patients, who hadhigh titer reactive HCV antibody. The test was repeated by another method (ELFA) in 30 patients with low titer HCV antibody. In 12 of these patients HCV antibodies were found to be non-reactive. All patients, who were screened for HCV antibody with ELFA, were HCV RNA negative. Only $41(0.17 \%)$ of 23980 samples, which were screened for the preoperative preparation, had reactive HCV antibody. Nine of these were HCV RNA positive. Two hundred and fourteen $(5.22 \%)$ of 4101 samples, which were obtained for diagnostic purposes in the gastroenterology and infectious diseases clinics, were reactive and 137 of them were HCV RNA positive.

HCV antibody and HCV RNA results for screening and diagnostic purposes are shown in Table 1.

\section{Discussion}

Laboratory tests have important roles in the diagnosis of HCV infection and monitoring of patients. Reactive test results for HCV antibodies, with values close to borderline limits, constitute a serious problem for routine diagnostic laboratories. Most of them are observed to be false positive results (5). In populations with low seroprevalence, false positivity is observed in blood and organ donors and in individuals with positive tests for rheumatoid factor (6). The incidence of HCV infection in Turkey is low with a rate of $1 \%$ (7). Therefore, in our country, there is a high probability of false positivity. It is suggested that repeated results of reactive $\mathrm{HCV}$ antibodies can be associated with current HCV infections, history of $\mathrm{HCV}$ infections or false-positive hepatitis $\mathrm{C}$ antibodies. HCV RNA testing is recommended to detect any present infection (4). In our study, we also used HCV RNA test. A correlation between S/CO for HCV antibodies and HCV infections has been reported. A S/ $\mathrm{CO}$ for determining the true $\mathrm{HCV}$ antibody positivity with a rate of $95 \%$ was determined to be $\geq 5.0$ for Architect Kit (4). Another study reported a positive predictive value of $95.4 \%$ when a S/CO of 5.0 was taken for Architect Kit (8). A study conducted in our country suggested that the use of a $\mathrm{S} / \mathrm{CO}$ of $\geq 5.0$ would be more appropriate in identifying HCV infections (9). Two hundred and fiftyfive samples, which have been tested for HCV RNA and with S/CO values of $\geq 1-<5.0$ and $\geq 5$ for HCV antibodies, have been included in our study. False positivity has been reported to be common in women and in the elderly due to their susceptibility to autoimmune diseases and infections, leading to decline HCV antibody titrations in years (5). Ecemiş et al. (9) determined HCV RNA positivity in $2(3.8 \%)$ out of 52 patients with a S/CO value of $\leq 5$ for $\mathrm{HCV}$ antibodies. Another study reported HCV RNA positivity in 3 (1.4\%) out of $215(0.9 \%)$ samples selected out of 25029 samples with S/ $\mathrm{CO}$ values between 1 and 5 for HCV antibodies (5). In our study, HCV RNA antibody was identified in 4 (5.8\%) out of 69 samples, in which low titer reactivity was detected and which were tested for viral load. On the other hand, HCV RNA positivity was identified in 142 (76.3\%) out of 186 samples with high titer reactive HCV antibody. Various studies have reported HCV RNA positivity rates of $43.8-68 \%$ in patients with identified $\mathrm{HCV}$ antibody reactivity $(10,11,12,13)$. In our study, out of $255 \mathrm{HCV}$ antibody reactive patients $146(57.3 \%)$ were identified with HCV RNA positivity. Given these results, it is concluded that especially samples with low titer reactive $\mathrm{HCV}$ antibodies may be false positives and that all positive results should be confirmed by HCV RNA testing.

\begin{tabular}{|l|l|l|l|l|l|l|}
\hline Table 1. Hepatitis C virus RNA results of anti-Hepatitis C virus reactive patients \\
\hline & $\begin{array}{l}\text { Low titer anti-HCV } \\
\text { positive (\%) }\end{array}$ & $\begin{array}{l}\text { HCV RNA } \\
\text { positive (\%) }\end{array}$ & $\begin{array}{l}\text { High titer anti- } \\
\text { HCV positive (\%) }\end{array}$ & $\begin{array}{l}\text { HCV RNA } \\
\text { positive (\%) }\end{array}$ & $\begin{array}{l}\text { Total anti-HCV } \\
\text { positive (\%) }\end{array}$ & $\begin{array}{l}\text { Total } \\
\text { HCV RNA positive (\%) }\end{array}$ \\
\hline Screening anti-HCV (23980) & $29(0.12)$ & - & $12(0.05)$ & $9(0.04)$ & $41(0.17)$ & $9(0.04)$ \\
\hline Diagnostic anti-HCV (4101) & $40(0.98)$ & $4(0.1)$ & $174(4.2)$ & $133(3.2)$ & $214(5.2)$ & $137(3.3)$ \\
\hline Total (28081) & $69(0.25)$ & $4(0.01)$ & $186(0.6)$ & $142(0.5)$ & $255(0.9)$ & $146(0.52)$ \\
\hline HCV: Hepatitis C virus
\end{tabular}


If distinguishing between true and false positivity is required and if multiple tests reveal positivity, it is emphasized that another type of HCV antibody test should be performed (4). In our study, 30 (all them were negative for HCV RNA) out of 69 samples with multiple HCV antibody test results with Architect i2000, and in which low titer reactivity was detected, were tested by VIDAS. Out of a total of 30 samples, 12 were detected to be non-reactive, whereas, 18 were detected to be reactive. Given these results, it is concluded that in almost half of the patients there was no need for HCV RNA testing. It is suggested that in cases with multiple test results showing reactivity, testing with another method for $\mathrm{HCV}$ antibodies may help reduce any unnecessary testing for HCV RNA.

A study conducted in Germany reported $0.04 \%$ positivity in patients who were screened pre-operatively. From the economic perspective, it was highlighted that routine preoperative screening should not be performed due to low rates of reactivity, and that screening only patients with risk factors would be as safe as screening all patients, and this might help reduce the costs (14). $\mathrm{HCV}$ screening is not recommended for preoperative preparations. However, it is recommended if exposure to HCV is in question and it is recommended in populations with high seroprevalence ( $2 \%$ to $5 \%$ of HCV antibody) $(2,4,15)$. The consensus report of the Study Group for Viral Hepatitis of the Turkish Society of Clinical Microbiology and Infectious Diseases-states that routine $\mathrm{HCV}$ screening tests are not required in our country as the prevalence of $\mathrm{HCV}$ is low and that HCV should be screened only in risk groups (3). In our study, the prevalence of HCV antibody positivity was determined to be $1.27 \%$. The incidence of HCV antibody positivity was found to be $0.9 \%$. Of 23980 samples tested for HCV antibodies for screening, $114(0.47 \%)$ of them were identified to be reactive for the first test. It is concluded that screening tests are unnecessary in the context of pre-operative preparations as it has been reported that they should not be performed because of being costly and, as they have not been recommended in the guidelines. In addition, in our study we also found low positivity rates.

\section{Conclusion}

We are of the following opinions that in accordance with the Centers for Disease Control and Prevention recommendations, positive results should be confirmed with HCV RNA testing; if possible, testing for $\mathrm{HCV}$ antibodies with other methods, before HCV RNA testing, will decrease the number of tests using molecular methods; and screening for HCV antibodies is not costeffective especially in populations with low prevalence of $\mathrm{HCV}$ antibody positivity.

\section{Ethics}

Ethics Committee Approval: Retrospective study.

Informed Consent: Retrospective study.

Peer-review: Externally peer-reviewed.

\section{Authorship Contributions}

Surgical and Medical Practices: Ö.T., Concept: B.Ş., Design: B.Ş., Data Collection or Processing: B.S.., A.E.T., Analysis or Interpretation: A.E.T., Literature Search: B.Ş., Writing: B.Ş., Ö.T., A.E.T.
Conflict of Interest: No conflict of interest was declared by the authors.

Financial Disclosure: The authors declared that this study received no financial support.

\section{References}

1. WHO Hepatitis C Fact sheet, updated October 2017. http:// www.who.int/mediacentre/factsheets/fs164/en/ laccessed 30 November 2017)

2. Guidelines for the screening, care and treatment of persons with chronic hepatitis C infection, updated version april 2016. http:// www.who.int/hepatitis/publications/hepatitis-c-guidelines-2016/ en/ (accessed 13 December 2017).

3. Aygen B, Demirtürk N, Türker N, Asan A, Eraksoy H, Gürbüz $Y$, Inan D, Keten D, Koçulu S, Öncü S, Özkaya D, Saltoğlu N, Sayan M, Süer K, Şener A, Tekin S, Tuna N, Yazıcı S. Management of Chronic Hepatitis C Virus Infection: A Consensus Report of the Study Group for Viral Hepatitis of the Turkish Society of Clinical Microbiology and Infectious Diseases-2017 Update. Klimik Dergisi. 2017;30(Özel Sayı 1):2-36.

4. Centers for Disease Control and Prevention (CDC). Testing for HCV Infection: An Update of Guidance for Clinicians and Laboratorians. MMWR Morb Mortal Wkly Rep. 2013;62:362-365.

5. Zer Y, Karaoğlan I, Çiçek H, Karagöz ID, Sağlam M. Evaluation of the patients with low levels of anti-HCV positivity. Mikrobiyol Bul. 2009;43:133-139.

6. Köse Ş, Ece G, Şamlıoğlu P, Topaloğlu S. Evaluation of HCV RNA levels in samples with low anti-hepatitis $C$ virus antibodies at Tepecik Education and Research Hospital. Turk Hij Den Biyol Derg. 2011;68:191-196.

7. TC Sağlık Bakanlığı Türkiye Halk Sağlığı Kurumu. BulaşıC Hastalıkların Laboratuvar $T$ anısı için Saha Rehberi. Ankara: Kolektif. 2014.

8. Wu S, Liu Y, Cheng L, Yin B, Peng J, Sun Z. Clinical evaluation of the signal-to-cutoff ratios of hepatitis $C$ virus antibody screening tests used in China. J Med Virol. 2011;83:1930-1937.

9. Ecemiş $T, A$,çalı $S$, Erbay Dündar $P$, Şanlıdağ $T$. The threshold value of Anti-HCV test in the diagnosis of HCV infection. Turkiye Klinikleri J Med Sci. 2012;32:1648-1652.

10. Vermehren J, Schlosser B, Domke D, Elanjimattom S, Müller C, Hintereder G, Hensel-Wiegel K, Tauber R, Berger A, Haas N, Walcher F, Möckel M, Lehmann R, Zeuzem S, Sarrazin C, Berg T. High Prevalence of Anti-HCV Antibodies in Two Metropolitan Emergency Departments in Germany: A Prospective Screening Analysis of 28,809 Patients. PLoS One. 2012;7:e41206.

11. Tolmane I, Rozentale B, Keiss J, Arsa F, Brigis G, Zvaigzne A. The prevalence of viral hepatitis $C$ in Latvia: a population-based study. Medicina (Kaunas). 2011;47:532-535.

12. Chlibek R, Smetana J, Sosovickova R, Gal P, Dite P, Stepanova $\checkmark$, Pliskova L, Plisek S. Prevalence of hepatitis C virus in adult population in the Czech Republic - time for birth cohort screening. PLoS One. 2017;12:e0175525.

13. Umumararungu E, Ntaganda F, Kagira J, Maina N. Prevalence of Hepatitis C Virus Infection and Its Risk Factors among Patients Attending Rwanda Military Hospital, Rwanda. Biomed Res Int. 2017;2017:5841272.

14. Weber $P$, Eberle J, Bogner JR, Schrimpf $F$, Jansson V, HuberWagner $\mathrm{S}$. Is there a benefit to a routine preoperative screening of infectivity for HIV, hepatitis B and C virus before elective orthopaedic operations? Infection. 2013;41:479-483.

15. Easterbrook PJ, Roberts T, Sands A, Peeling R. Diagnosis of viral hepatitis. Curr Opin HIV AIDS. 2017;12:302-314. 